\title{
The housekeeping gene xanthine oxidoreductase is necessary for milk fat droplet enveloping and secretion: gene sharing in the lactating mammary gland
}

\author{
Claudia Vorbach, ${ }^{1}$ Alistair Scriven, ${ }^{2}$ and Mario R. Capecchi ${ }^{1,3}$ \\ ${ }^{1}$ Howard Hughes Medical Institute, Department of Human Genetics, University of Utah, Salt Lake City, Utah, 84112, \\ USA; ${ }^{2}$ Career Development, Medical Research Service, Department of Veterans Affairs Medical Center, \\ Salt Lake City, Utah 84148, USA
}

Xanthine oxidoreductase (XOR) is the rate-limiting enzyme in purine catabolism occurring in most cell types. However, this housekeeping gene is expressed at very high levels in a number of mammalian tissues including the lactating mammary epithelium, suggesting additional roles for XOR in these tissues. Mice with targeted disruption of $X O R$ were generated to assess these potential additional roles. $X O R-/-$ mice are runted and do not live beyond $6 \mathrm{wk}$ of age. Strikingly, however, $\mathrm{XOR}+/$ - females, although of healthy appearance and normal fertility, are unable to maintain lactation and their pups die of starvation 2 wk postpartum. Histological and whole-mount analyses showed that in $\mathrm{XOR}+$ - females the mammary epithelium collapses, resulting in premature involution of the mammary gland. Electron microscopy showed that XOR is specifically required for enveloping milk fat droplets with the apical plasma membrane prior to secretion from the lactating mammary gland. We present evidence that XOR may have primarily a structural role, as a membrane-associated protein, in milk fat droplet secretion and thus XOR provides another example of "gene sharing". About $5 \%$ of women experience primary lactation insufficiency. The above observations suggest that human females suffering from xanthinuria, a deficiency in XOR, are potential candidates for lactation problems.

[Keywords: Xanthine oxidoreductase; mammary gland; lactation; fat droplet; enveloping; gene sharing]

Received August 14, 2002; revised version accepted October 28, 2002.

Xanthine oxidoreductase $(X O R)$ is a housekeeping gene that encodes a molybdenum iron-sulfur flavin hydroxylase found in all organisms. In vitro experiments show that XOR is a relatively nonspecific, multifunctional enzyme, capable of oxidizing a variety of substrates including purines, pyridine dinucleotides, pteridines, and aldehydes. Although it is one of the best studied enzymes in vitro, the complexities of its in vivo functions are less well understood. In vertebrates, a primary role of XOR is its participation in purine catabolism. The holo-enzyme exists as a homodimer and is composed of two identical and catalytically independent subunits, each containing two [2Fe-2S] groups, one $\mathrm{FAD}$, and one molybdopterin (Rajagopalan and Handler 1967; Massey et al. 1969; Bray et al. 1975; Carpani et al. 1990; Cazzaniga et al. 1994; Hille and Nishino 1995).

XOR can be isolated as two distinct enzymatic forms from most biological sources: either as xanthine dehydrogenase (XD; EC 1.1.1.204) or as xanthine oxidase (XO;

${ }^{3}$ Correspondig author.

E-MAIL mario.capecchi@genetics.utah.edu; FAX (801) 585-3425.

Article and publication are at http://www.genesdev.org/cgi/doi/10.1101/ gad.1032702.
EC 1.1.3.22). The mammalian XD and $\mathrm{XO}$ forms are interconvertible in vitro (Waud and Rajagopalan 1976; Amaya et al. 1990). XD is the predominant enzymatic form found in normal tissues, while the XO form dominates in tissues subjected to injury. The different structural and catalytic activities as well as the preference for different oxidation substrates is derived from an additional $\mathrm{NAD}^{+}$binding site in $\mathrm{XD}$. Hence, with $\mathrm{XD}$, the reducing equivalents generated by the oxidation of substrates are transferred to $\mathrm{NAD}^{+}$, whereas $\mathrm{XO}$ is unable to bind $\mathrm{NAD}^{+}$and exclusively uses $\mathrm{O}_{2}$ as its electron acceptor. The latter reaction results in the production of reactive oxygen species (ROS) as a metabolic byproduct. ROS are produced excessively under certain pathophysiological conditions and, for this reason, the conversion of $\mathrm{XD}$ to $\mathrm{XO}$ is of major medical interest. $\mathrm{XO}$ has been implicated in many diseases associated with oxygenradical-induced tissue damage, contributing to postischemic reperfusion injuries, as well as aging (Fridovich 1970; Parks and Granger 1983; McCord 1985; Granger et al. 1986; Engerson et al. 1987; Chung et al. 1999).

Besides its role as a housekeeping gene, $X O R$ is highly expressed in liver and kidney, the main organs involved 
in purine catabolism and nitrogen elimination. Furthermore, it is found at high levels in a number of other mammalian tissues and organs, including the mammary gland (Jarasch et al. 1981; Kurosaki et al. 1995, 1996). This suggests that XOR plays additional roles in these tissues beyond its metabolic function(s). In humans, deficiencies of the enzyme are known to result in xanthinuria, an autosomal-recessive disorder leading to kidney stone formation, urinary tract disorders, and muscle diseases (Dent and Philport 1954). However, no other histological or physiological symptoms have been associated with reduced activity of XOR.

It has long been known that cow milk contains high levels of XOR activity. Expression of XOR in the lactating mammary gland is restricted to the secretory epithelium. In vitro analyses show that the transcription, translation, and enzymatic activity of XOR are up-regulated during late pregnancy and throughout lactation. XOR has therefore been used as a marker for terminal differentiation of mammary epithelial cells. Interestingly, XOR expression levels positively correlate with the secretory activity of the mammary epithelial cells. Furthermore, XOR expression is highly induced by lactogenic hormones (Schardinger 1902; Massey et al. 1969; Hayden et al. 1991; Abadeh et al. 1992; Hunt and Massey 1992; Linder et al. 1999; McManaman et al. 1999, 2000). These observations support the idea that XOR has a specific role in the mammary gland during lactation. By generating mice containing a targeted disruption in $X O R$, it has been possible to study this role. We demonstrate that female mice heterozygous for a $X O R$ loss-offunction mutation are unable to maintain lactation due to failure to secrete fat droplets into the milk.

\section{Results}

\section{Generation of mice deficient for XOR}

$\mathrm{XOR}$ is the product of a single gene containing 36 exons. Using homologous recombination in embryonic stem (ES) cells (Capecchi 1989) mice carrying a null mutation for $X O R$ were generated by inserting, in frame, the Green Fluorescent Protein (GFP) gene and a loxP/tACE-Cre/ $n e o^{r} / l_{o x} P$-cassette into the third exon of $X O R$ (Fig. 1A). The mutant $X O R$ gene produces a truncated protein composed of exons 1,2 , and a portion of exon 3 fused to GFP. The Cre/neo ${ }^{r}$ cassette in the mutant $X O R$ allele is automatically excised from the locus in sperm produced by the chimeric animals that were generated from these ES cells (Bunting et al. 1999).

\section{Pups from XOR+/- females die at approximately 12 days postpartum}

Mice homozygous $(-/-)$ for the mutation in $X O R$ are runted and do not live beyond 6 wk of age. $X O R$ heterozygous $(+/-)$ mice are viable and show normal fertility, litter size, and maternal behavior. However, all pups from $X O R+/-$ females, regardless of genotype, die around day 12 postpartum (P12) of malnourishment. In contrast to controls, dissected pups born to these females were
A
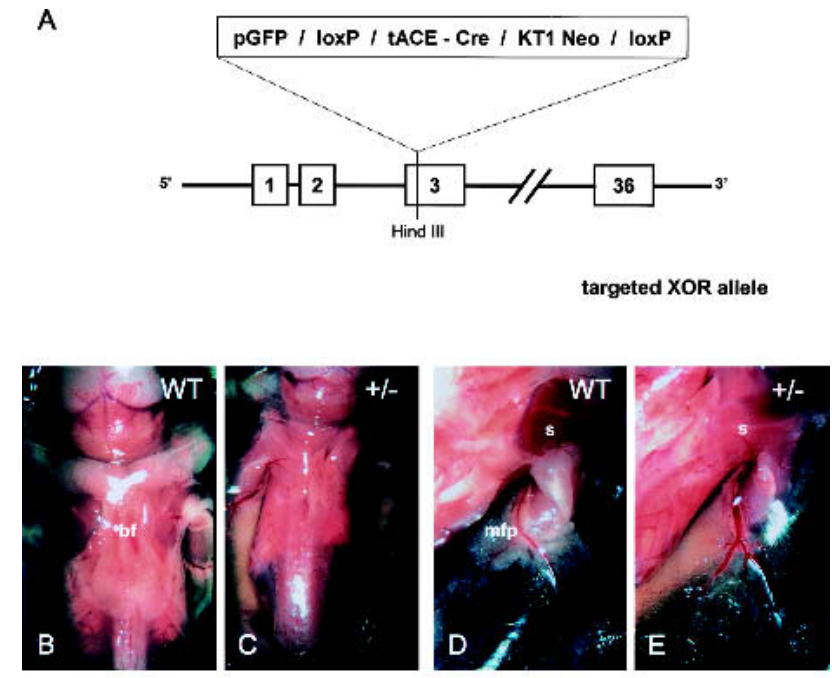

F

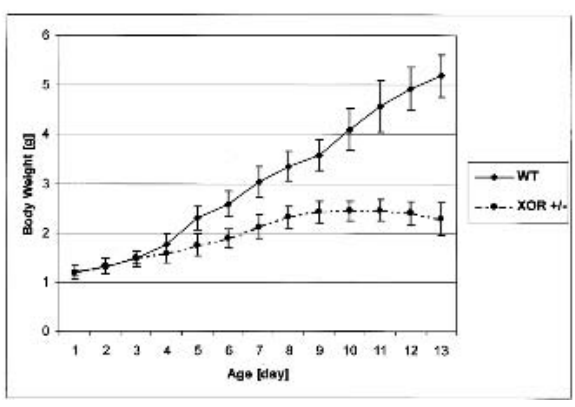

Figure 1. Targeting strategy for disruption of the $X O R$ gene and pathology of pups raised by $X O R+/-$ mothers. $(A)$ A cassette containing $p G F P / /$ ox $P /$ tACE-Cre $/$ neo $^{r} /$ lox $P$ was inserted into the HindIII restriction site of the third exon of $X O R$ genomic sequence, creating a loss-of-function mutation. Exons are shown as boxes and identified numerically. $(B-E)$ Pups of wildtype (WT) and $X O R+/-$ mothers at P12. Pups from $X O R+/-$ mothers do not have the body fat stores of brown fat $(C)$ and mammary fat pads $(E)$ that age-matched pups from wild-type mothers have $(B, D)$. bf, brown fat; mfp, mammary fat pad; $\mathrm{s}$, scapula. $(F)$ Average body weight increase of pups nursed by

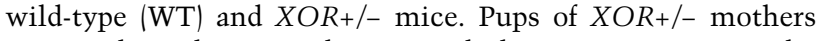
start to die at lactation day 12 . Each data point represents the average of 3 litters each with 6 pups $(\mathrm{n}=18)$. Data are means \pm S.D. Magnification: $B, C, 2.5 \times ; D, E, 4 \times$.

found to be devoid of adipose tissue, such as brown fat and mammary fat pads (Fig. 1B-E). In addition, skeletal muscles were reduced in volume, consistent with starvation (data not shown). The bladders of the pups from $X O R+/-$ mothers were normal and filled with urine (data not shown), indicating that dehydration was not the cause of death. To further analyze this process, the body weight of litters nursed by either wild-type or $\mathrm{XOR+/-}$ mice was monitored between birth and P13 (Fig. 1F). Until P4, the average body weight of the pups nursed by $X O R+/-$ mothers was not significantly different from control pups. Pups nursed by $X O R+/-$ mothers began to appear visibly malnourished by P6. By P12, when pups from the mutant mothers begin to die, the pups were emaciated, and by $\mathrm{P} 13$, the remaining pups showed less 
than $50 \%$ of the body weight of the control litter. Fostering experiments showed that pups from $X O R+/-$ mice can be raised normally by wild-type mothers (data not shown).

\section{Mammary glands of $\mathrm{XOR}+/-$ mice undergo tissue destruction during lactation}

The development of the mammary glands in wild-type and $X O R+/-$ mice was examined in $H \& E$ stained paraffin sections and whole-mount preparations during late pregnancy and throughout lactation. No differences were found during pregnancy (data not shown) or at lactation day 1. The development of epithelial lobular-alveolar structure and the amount of adipocyte tissue appeared to be the same in wild-type and $X O R+/-$ mammary glands on this day (Fig. 2A,B,I,J). By lactation day 5, the mammary epithelium of wild-type and $X O R+/-$ glands proliferated and showed many expanded alveoli, indicating active milk secretion (Fig. 2C,D,K,L). The epithelium from
$X O R+/-$ mammary glands appeared similar; however, more adipocytes, which shrink in volume to provide fatty acids for milk fat synthesis, were still visible (Fig. 2D). In addition, within numerous mammary alveoli of the $X O R+/-$ mice cell blebbing was detected; some of those cytoplasmic fragments were associated with milk fat droplets (Fig. 2D,L, arrows). At lactation day 11, the wild-type mammary alveoli expanded further, correlating with increased milk synthesis, secretion, and pup size (Fig. 2E,M). The XOR+/- mammary epithelium, however, showed severe cell shedding and tissue fragmentation associated with loss of epithelial tissue volume and premature tissue involution (Fig. 2F,N). By lactation day 13 , severe tissue remodeling in the $X O R+/-$ mammary epithelium resulted in the collapse of many mammary alveoli and less epithelial tissue remained throughout the mammary gland (Fig. $2 \mathrm{H}, \mathrm{P})$. The majority of the epithelial tissue appeared to be lactation deficient. However, some of the alveoli still seemed ex-
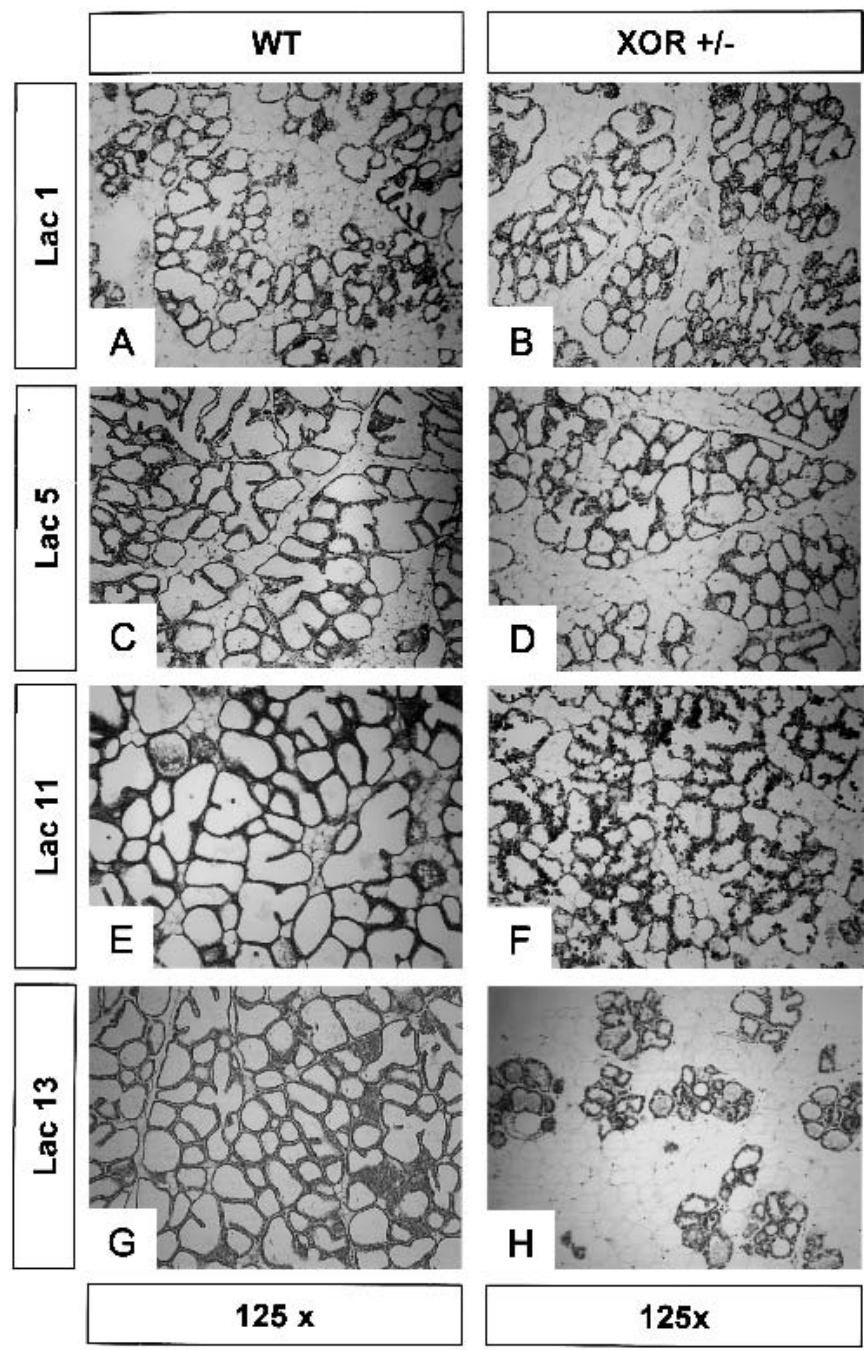
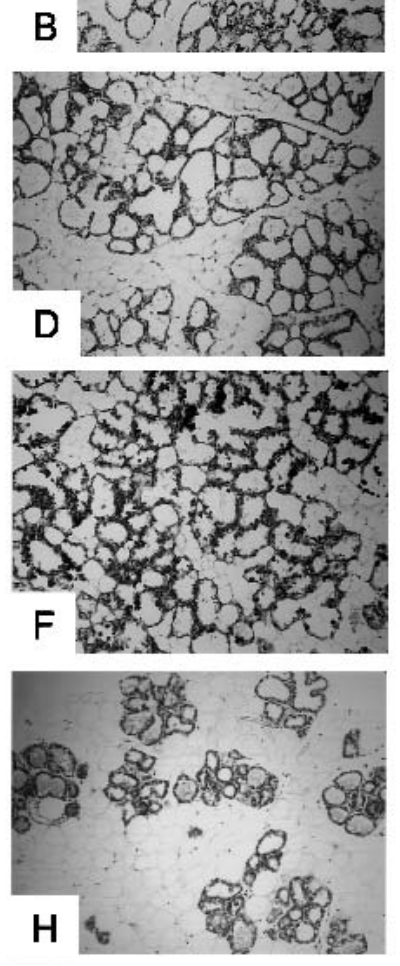

$125 x$
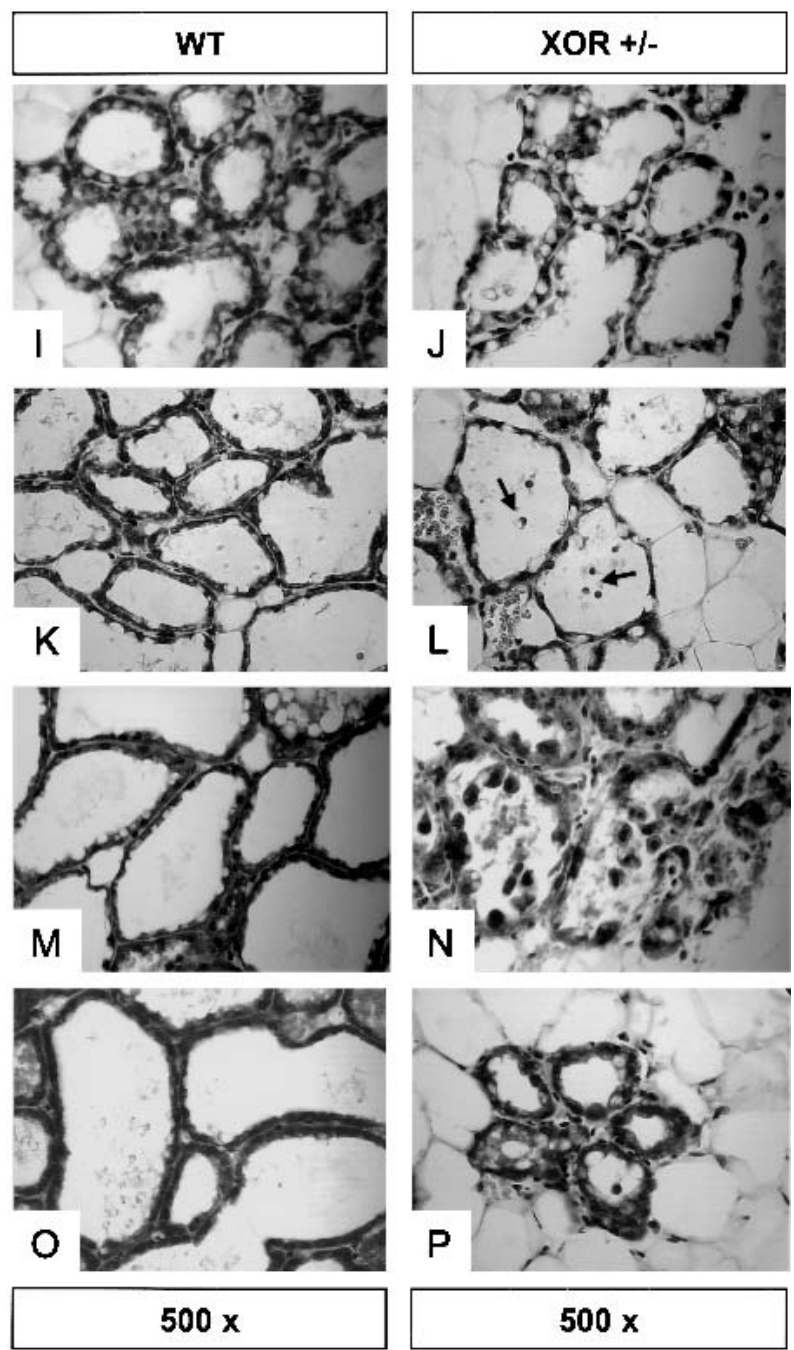

Figure 2. Histological analysis of normal and $X O R+/-$ mammary glands. $(A-P)$ Paraffin sections of mammary glands taken at various times during lactation and stained with hematoxylin and eosin. $X O R+/-$ mammary epithelium undergoes destruction within the first half of lactation. Glands at lactation days $1(A, B, I, J), 5(C, D, K, L), 11(E, F, M, N)$, and $13(G, H, O, P)$. WT mammary glands are shown in $A, C, E, G, I, K, M, O$. XOR+/- mammary glands are shown in $B, D, F, H, J, L, N, P$. Magnification, $125 \times$ and $500 \times$. 
panded due to milk secretion and many of the mammary epithelial cells still contained fat droplets, indicating that mammary tissue destruction was independent of a defect in lactogenic hormones. Overall, tissue damage in the $X O R+/-$ mammary gland correlates with the time course of pup starvation. An analysis of whole-mount preparations of wild-type and $X O R+/-$ mammary glands at lactation day 13 revealed again the overall collapse of the $X O R+/-$ epithelial tissue (Fig. 3A,B). However, only the secretory portion of the gland, the milk secreting

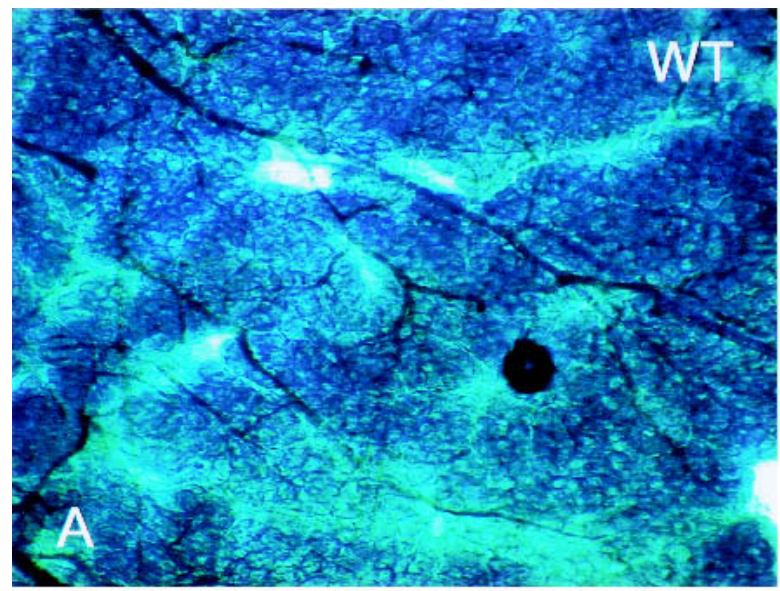

alveoli, were affected, while the ducts, which mainly transport the secretions to the exterior of the gland, appeared normal (Fig. 3B, red arrows).

The enzymatic activity of $X O R$ is reduced in terminally differentiated XOR+/- mammary glands

Previous studies have shown that the enzymatic activity and expression level of XOR increase during late pregnancy and remain high throughout lactation (Kurosaki et

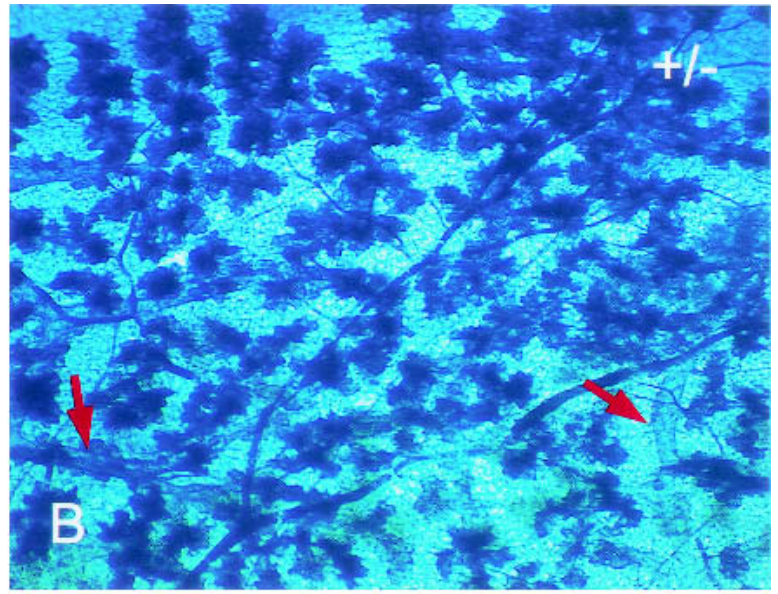

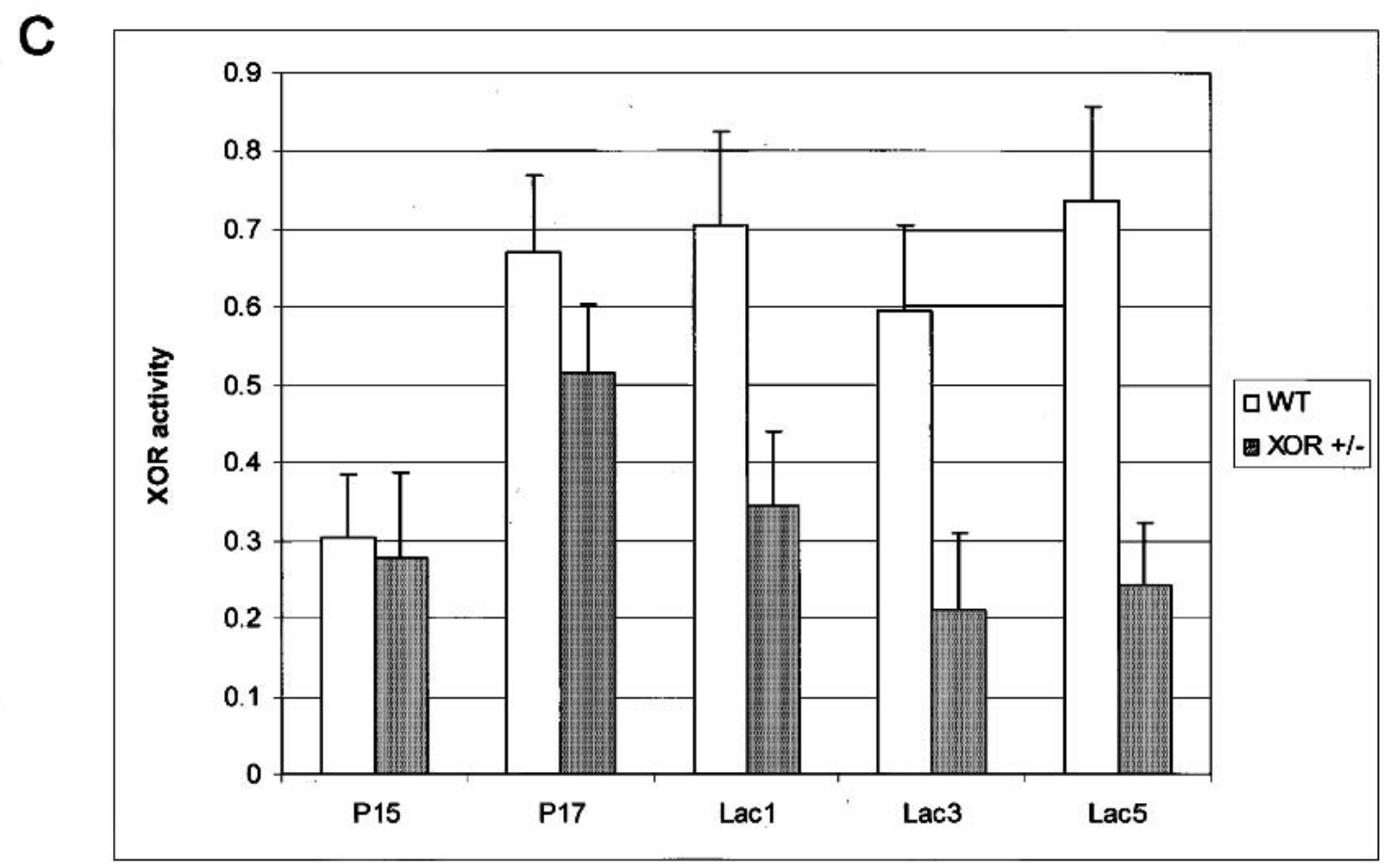

Figure 3. Whole-mount analysis and XOR enzymatic activity of wild-type and $X O R+/-$ mammary glands. $(A, B)$ Whole-mount analysis of wild-type (WT, $A$ ) and $X O R+/-(B)$ mammary glands at lactation day 13 . The milk-secreting alveoli are collapsed in $X O R+/-$ mammary glands compared to wild-type, while the ducts are unaffected (red arrows). Tissue was stained with indigo carmine alum. (C) Reduced XOR enzymatic activity in terminally differentiated XOR+/- mammary glands. XOR activity in mammary glands of wild-type (WT) and $X O R+/-$ mice was measured during late pregnancy $(\mathrm{P})$ and early lactation (Lac). XOR activity is expressed as micromolar of isoxantho-pterin formed/minutes per milligrams of total mammary gland protein. Each value is the mean \pm S.D. of eight separate tissue extracts. Magnification: $A, B, 31.25 \times$. 
al. 1996; McManaman et al. 1999). To determine whether the absence of one allele of $X O R$ results in reduced enzymatic activity of XOR in the mammary gland, the level of XOR activity was determined at multiple time points throughout late pregnancy and early lactation. At pregnancy day 15, wild-type and $X O R+/-$ mammary glands showed similar levels of enzymatic activity (Fig. 3C). During later pregnancy, XOR activity was increased in accordance with earlier reported analyses. However, enzymatic activity increased less in $X O R+/-$ mammary glands than in wild-type glands. In addition, while XOR activity remained high in the wildtype mammary glands throughout lactation, the enzymatic activity in $X O R+/-$ glands steadily decreased postpartum, which correlates with the destruction of lactating mammary epithelium in the $X O R+/-$ mice. Additional analyses of XOR activity in various organs of $X O R+/-$ mice showed that the enzymatic activity of $\mathrm{XOR}$ is about $50 \%$ less than in wild-type tissue (A.J. Scriven and M.R. Capecchi, in prep.).

\section{Milk fat droplets accumulate in the mammary epithelium of $\mathrm{XOR}+/-$ mice}

Toluidine blue stained semithin sections showed that already by lactation day 1 , milk secretion was perturbed in $X O R+/-$ mice. Most fat droplets in wild-type mammary glands were secreted and accumulated in the lumen of the alveoli (Fig. 4A). Only a few wild-type epithelial cells contained cytoplasmic fat droplets. However, in the $X O R+/-$ mammary gland, secretion of milk fat droplets was perturbed and cytoplasmic fat droplets accumulated in most of the mammary epithelial cells (Fig. 4B). Few fat droplets were successfully secreted into the lumen of the $X O R+/-$ alveoli, although some appeared to be forced out (Fig. 4B, red arrows). In addition, the accumulated fat droplets in the $X O R+/-$ epithelial cells were often very large, presumably due to ongoing fat droplet synthesis and fusion with smaller droplets. Still, the lumen of $X O R+/-$ mammary glands appeared to be rich in colloidal particles, known as the casein micelle (Fig. 4B, dark dots in the lumen of the mammary gland alveoli), suggesting that protein secretion is normal and only fat droplet secretion is defective. To determine if protein secretion is altered in $X O R+/-$ mammary glands, milk protein content from $X O R+/-$ and wild-type mice was compared. Electrophoretic separation of milk samples from lactation days 2-6 showed no difference in major milk protein content (data not shown).

The accumulation of milk fat droplets in the $X O R+/-$ mammary tissue was also verified following food deprivation. Milk fat is the major calorie supply for newborns, and its synthesis is very sensitive to the mother's calorie intake and/or body fat. Rodents have very little metabolic reserve in comparison to their rate of milk synthesis, and prolonged food deprivation leads to a state of starvation with a significant effect on the synthesis of all milk components (Williamson 1990). After depriving wild-type and $X O R+/-$ mice of food for about $30 \mathrm{~h}$ starting at lactation day 1 , wild-type mammary epithelium
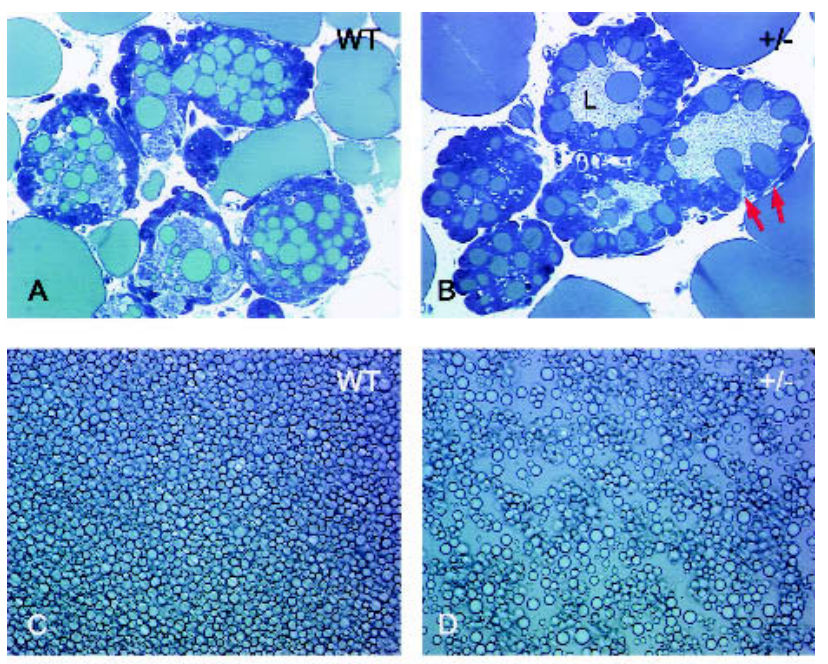

E

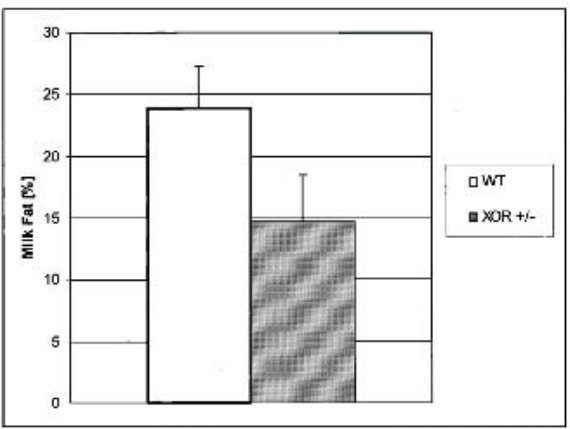

Figure 4. Milk fat droplets accumulate in $X O R+/-$ mammary epithelium and less fat is formed in $X O R+/-$ milk. $(A, B)$ Histological analysis of resin-embedded mammary glands of wildtype (WT, $A$ ) and $X O R+/-(B)$ mice at lactation day 1 . The red arrows indicate $X O R+/-$ epithelial cells that try to force out accumulated fat droplets. L, lumen of the mammary alveoli. $(C, D)$ Lactating wild-type (WT) and $X O R+/-$ mice were milked for milk fat analysis. Light microscopic analysis of milk samples show that $X O R+/-(B)$ milk contains fewer fat droplets than milk from wild-type (WT, $A)$ mice. $(E)$ Creamatocrit analysis estimates $23.9 \%$ of average milk fat in WT mice, while only $14.7 \%$ in milk of $X O R+/-$ mice. Values are the mean \pm S.D. of 10 separate milk samples from lactation day 2. Magnification: $A-D, 500 \times$

was completely depleted of fat droplets, owing to the absence of additional milk fat synthesis. Previously synthesized milk fat droplets were secreted and some were still found in the lumen. However, the XOR+/- mammary epithelium still contained a significant number of fat droplets, again consistent with a defect in their secretion (data not shown). Further analyses of milk fat using microscopy and creamatocrit analysis show a reduction of milk fat content in the $X O R+/-$ milk compared to wild-type milk (Fig. 4C-E).

Defective enveloping of milk fat droplets with the apical epithelial plasma membrane in $\mathrm{XOR}+/-$ mammary glands

Most milk components are secreted from the mammary epithelium by exocytosis, while milk fat droplet secre- 
tion occurs by a unique mechanism. Cytoplasmic fat droplets are surrounded by a monolayer derived from the membranes of the ER in which fat droplet synthesis takes place. During the process of milk secretion, fat droplets become further enveloped by a bilayer of phospholipids derived from the apical plasma membrane from where they bud into the lumen of the mammary alveoli. To analyze the fat droplet secretion defects in the $X O R+/-$ mammary gland on a subcellular level, transmission electron microscopy (TEM) was performed. TEM analyses of lactating mammary glands at lactation days 1-5 show that the mechanism of milk fat droplet enveloping is perturbed in $X O R+/-$ mammary glands. In wild-type glands, each fat droplet was tightly enveloped with the apical membrane prior to secretion. Once a milk fat droplet was successfully secreted, the bilayer membrane was clearly visible around the floating fat droplet (Fig. 5A, arrows). In contrast, in XOR+/- mammary glands, some fat droplets became severely deformed during the process of secretion and were enveloped by a very abnormal membrane (Fig. 5B, black arrow). Figure 5C shows complete absence of milk fat droplet enveloping by the apical membrane. The entire fat droplet is still surrounded by cytoplasm as it was forced out of the cell (black arrow). In other cases, fat droplets burst while being secreted (Fig. 5D, black arrows). Some fat droplets seemed to be partially enveloped, yet other areas showed cytoplasmic crescents (Fig. $5 \mathrm{E}$, black arrows). Incomplete enveloping by the apical membrane was also seen with deformation of the fat droplet where it remained nonenveloped (Fig. 5F).

TEM examination of lactating wild-type and $\mathrm{XOR}+/-$ mammary alveoli also showed numerous abnormal milk fat droplets as well as various cell fragments floating in the milk of lactating $X O R+/-$ mice. Milk fat droplets from wild-type mammary glands were tightly enveloped with epithelial plasma membrane, which subsequently stabilizes the free-floating droplets (Fig. 5G). Numerous milk fat droplets in $X O R+/-$ mammary glands contained cytoplasmic crescents of various sizes (Fig. 5H,I, black arrows). Fat droplets with cytoplasmic crescents also occur naturally in the milk of many mammalian species (Huston and Patton 1990) but wild-type mice showed very few. Furthermore, milk fat droplets with very abnormal surrounding membranes (Fig. 5I, white arrows), partially enveloped milk fat droplets (Fig. 5J, white arrows), burst milk fat droplets (Fig. 5J,K, black arrows), as well as many budded cell fragments, often containing secretory vesicles filled with casein micelles (Fig. 5L; black arrows point to cell fragments, white arrow points to secretory vesicle) were found in milk of $X O R+/-$ mice.

Secreted milk fat droplets in early lactating XOR+/mice show various membrane phenotypes

TEM analyses of milk fat droplet membranes revealed various membrane phenotypes in $\mathrm{XOR}+/-$ milk. Some droplets appeared correctly enveloped with the apical plasma bilayer as found in wild-type (Fig. 6A, white arrow). Others contained the cytoplasmic fat droplet monolayer with unidentified associated structures (Fig. 6A, white arrowhead). As the enlargement in Figure 6B shows, these rounded structures appear to be under the fat droplet monolayer and are not associated with this membrane (white arrowhead). Therefore, they are not likely to be secreted milk proteins. Milk fat droplets that did not contain any membrane at all and burst through the cytoplasmic fat droplet monolayer, were also observed (Fig. 6A, black arrow). In some instances, different membrane phenotypes could be identified on a single $X O R+/-$ milk fat droplet (Fig. 6C). Normal bilayer membrane (white arrow), a region with the unidentified associated structure (white arrowhead), and a small cytoplasmic crescent (black arrow) were all observed together. Figure 6D shows a milk fat droplet that was partly enveloped, but as there was still some cytoplasm between the apical membrane and the fat droplet, the envelopment was not stable and the membrane seems to be breaking off (arrow).

Defective enveloping of milk fat droplets in lactating $\mathrm{XOR}+/-$ mammary glands causes tissue necrosis and premature involution of the mammary epithelium

As light microscopy analyses demonstrated, the defect in milk fat droplet secretion in the $X O R+/-$ mammary gland severely impacts the epithelial cells, causing the destruction of the epithelium in several ways. TEM analysis detected entirely destroyed mammary epithelial cells within secretory $X O R+/-$ alveoli at a subcellular level. Figure $6 \mathrm{E}$ shows a section of a milk secreting $X O R+/-$ alveolus with several epithelial cells that have deteriorated by lactation day 3 (arrows). The enlargement of burst epithelial cells in Figure 6F shows the large amount of mitochondria and ER membranes that are typical for lactating mammary epithelial cells (arrows). This again demonstrates on a subcellular level the tremendous damage the defect in milk fat droplet enveloping causes to the entire lactating mammary gland, resulting in tissue necrosis, premature involution of the epithelium, starvation, and death of the offspring.

\section{Discussion}

A genetic functional analysis of $X O R^{\prime}$ s role in mammalian lactation is provided. We demonstrate that XOR is required in the lactating mammary gland for milk fat droplet enveloping with the apical epithelial plasma membrane and subsequent secretion via budding from the terminal differentiated mammary epithelium. The defect in milk fat droplet secretion in the $X O R+/-$ mice causes the rupture of the lactating mammary epithelium, resulting in premature involution of the mammary gland and starvation of the offspring during the second week of lactation.

The mechanism of milk fat droplet secretion is unique to the mammary epithelium. Unfortunately, the cellular mechanisms of fat droplet synthesis and secretion are still poorly understood (Keenan 2001). Fat droplet syn- 

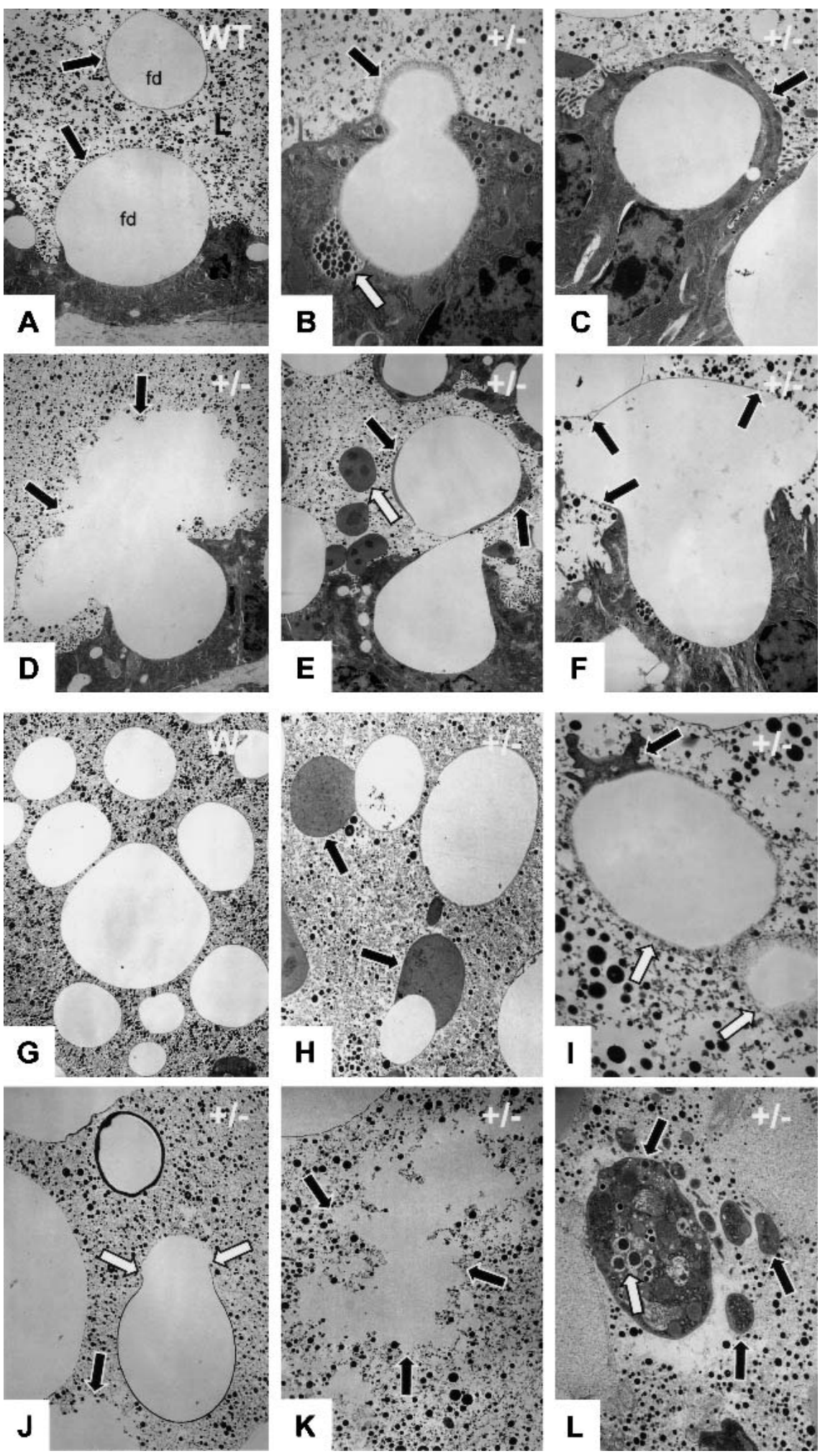

Figure 5. The mechanism of milk fat droplet enveloping with the apical plasma membrane is disturbed in $X O R+/-$ mammary glands. $(A-F)$ TEM analysis of wild-type (WT, $A)$ and $X O R+/-(B-F)$ mammary glands at lactation day 3 . Defective enveloping results in several fat droplet secretion phenotypes in the $X O R+/-$ mammary glands. L, lumen of the mammary gland filled with casein micelles. (G-L) TEM analysis of milk in mammary alveoli at lactation day 3 from wild-type $(\mathrm{WT}, G)$ and $X O R+/-(H-L)$ mammary glands. Various deformed fat droplets and numerous cell fragments are found in milk from $X O R+/-$ mice. Magnification: $A-F, 6000 \times-10,000 \times$; $G-L$, $5000 x-15,000 x$ 
Vorbach et al.
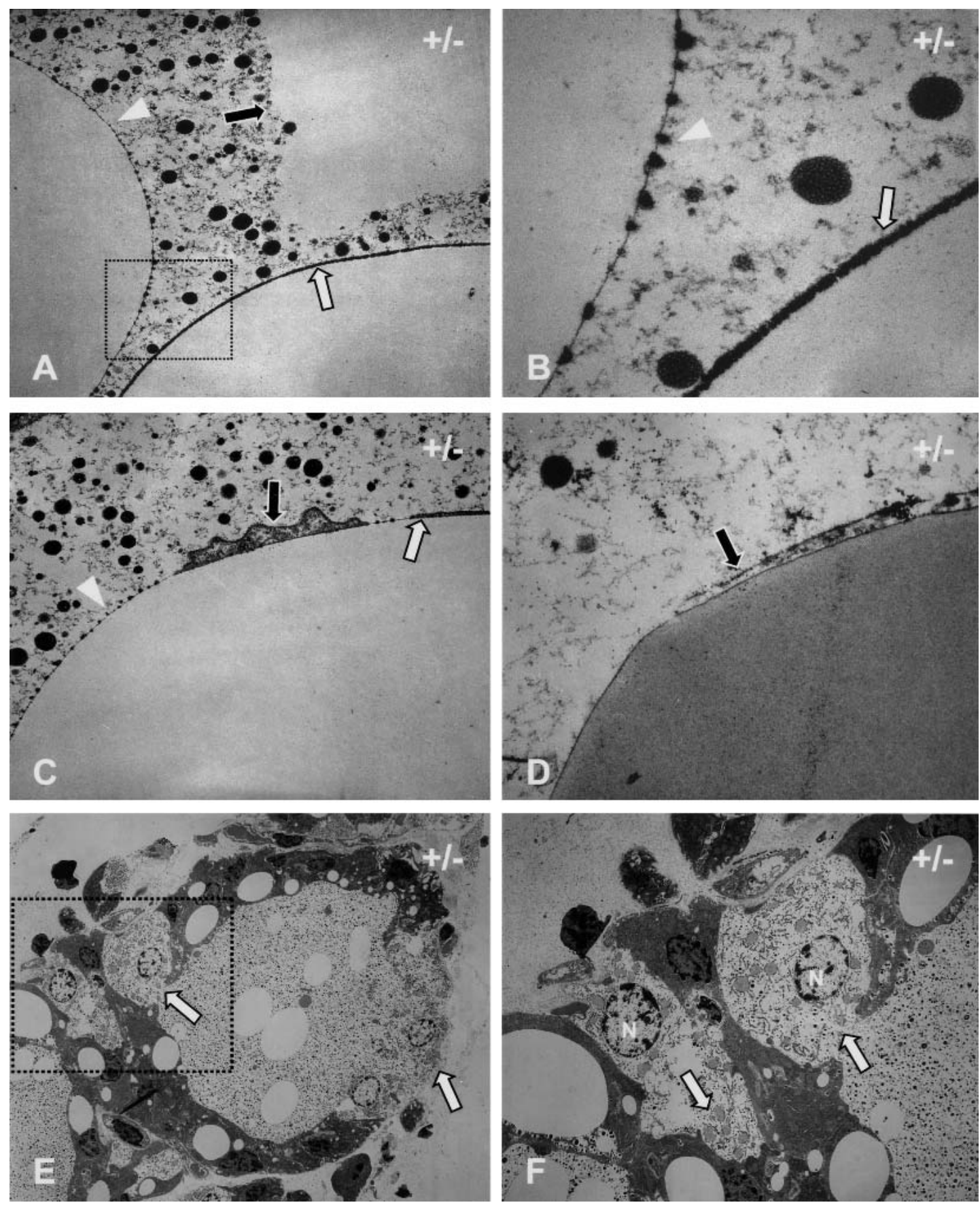

Figure 6. Various membrane defects in milk fat droplets from $X O R+/-$ mice. $(A-D)$ TEM analysis of milk fat droplets from $X O R+/-$ mammary glands at lactation day 3. (A) The white arrow points to a bilayer membrane of correctly enveloped fat droplet areas as found in wild-type. The black arrow points to a completely unenveloped droplet. The white arrowhead points to an unidentified membrane structure discussed in the text. $(B)$ Higher-power view of the boxed area in $A$. $(C)$ Three membrane phenotypes can be found on a single $X O R+/-$ milk fat droplet. The white arrow points to a portion of normal membrane bilayer. The black arrow indicates a piece of cytoplasmic crescent. Another portion of the fat droplet is occupied by the unidentified membrane structure as seen in $A$ and $B$ (white arrowhead). (D) XOR+/- milk fat droplet with a portion of cytoplasmic crescent that is only loosely associated with the droplet. (E) TEM analysis of an entire alveolus in a $X O R+/-$ mammary gland at lactation day 3 . The arrows point to completely destroyed mammary epithelial cells. $(F)$ Higher-power view of boxed area in $(E)$. Numerous free-floating mitochondria and ER are seen in burst cells of $X O R+/-$ mammary glands (white arrows). $\mathrm{N}$, nucleus. Magnification: $A, 30,000 \times ; B, 70,000 \times ; C, D, 50,000 \times ; E, 1000 \times ; F, 3000 \times$.

thesis occurs de novo in the ER from which fat droplets are released as microlipids surrounded by a monolayer of phospholipids and associated proteins (Ghosal et al. 1994). Fat droplets presumably form in the hydrophobic 
center of the ER bilayer and growth of the fat droplets appears to drive the opposing ER membrane monolayers apart, resulting in a bulge that buds into the cytoplasm (Long and Patton 1978; Zaczek and Keenan 1990). A transport system is proposed to bring the microlipid droplets to the apical membrane of the mammary epithelial cells. Throughout this transport process microlipids fuse to larger cytoplasmic lipid droplets (CLDs). The CLDs become tightly enveloped with the apical plasma membrane and finally bud off into the lumen of mammary alveoli (Mather and Keenan 1998). The present study demonstrates that milk fat droplet synthesis, fusion, and apical transport appear to be normal in the lactating $X O R+/-$ mice. Only the final step, enveloping the milk fat droplets with apical membrane prior to secretion, is abnormal.

The molecules that mediate enveloping of milk fat droplets are proteins associated with and integrated into the apical mammary epithelial membrane as well as the proteins found on CLDs. Most of these proteins are not expressed in undifferentiated mammary glands. Numerous milk fat globule membrane (MFGM) proteins have been isolated and characterized from milk fat of several species, and their subcellular orientations have been determined (Mather 2000). Interestingly, XOR is the second most common protein among the major MFGM proteins, comprising as much as $13 \%$ of total proteins. It has been estimated that XOR concentration increases $>150$ fold in the MFGM over its levels in the cytoplasm. While several of the MFGM proteins are integral transmembrane proteins, XOR is a globular cytoplasmic protein tightly associated with the membrane (Jarasch et al. 1977; Mangino and Brunner 1977; Freudenstein et al. 1979; Franke et al. 1981; Mather et al. 1982; Keenan and Patton 1995; McManaman et al. 1999). The presence of XOR among MFGM proteins and its strong epithelial expression during lactation, provides strong supporting evidence that the $\mathrm{XOR}+/$ - lactation phenotype is due to a defect within the mammary epithelium and not for example, due to a systemic defect of lactogenic hormones. Hormonal defects are also unlikely in the $X O R+/-$ mice, since reproduction occurs normally.

But what is the function of XOR during milk fat droplet secretion? The role XOR plays in fat droplet enveloping is unlikely to involve purine catabolism for several reasons: (1) Although XOR expression and enzymatic activity are greatly increased during late pregnancy and throughout lactation, uric acid, the end product of purine catabolism, is found only at low levels in the mammary gland; (2) whereas the dehydrogenase form (XD) of XOR is predominantly responsible for purine catabolism in all cells, it is the oxidase form (XO) of XOR that associates with MFGM and also predominates in milk. Studies have shown that milk XO has a very low activity towards purines, again indicating that the mammary-specific role of XOR is distinct from purine catabolism $(\mathrm{Ku}-$ rosaki et al. 1996). Interestingly, the MFGM itself is competent to induce the transition from the $\mathrm{XD}$ to the $\mathrm{XO}$ form, and this may be the important signal for the initiation of fat droplet enveloping and secretion (Mc-
Manaman et al. 1999). A study comparing bovine milk $\mathrm{XD}$ and $\mathrm{XO}$ crystal structures suggests that the reversible transformation of $\mathrm{XD}$ to $\mathrm{XO}$ is associated with a conformational change of the molecule due to formation of disulfide bonds (Enroth et al. 2000).

Our study suggests that XOR has a function in the mammary gland distinct from its catabolic function(s), and moreover that this function may be entirely structural and nonenzymatic. This hypothesis is further supported by the observed severity of the phenotype associated with the haploinsufficiency of XOR. The time course for the loss of lactation and of fat droplet secretion is consistent with progressive exhaustion of a membrane-associated structural component, rather than a reduction by $50 \%$ of an enzymatic activity.

The catalytic activity of XOR depends on the molybdenum cofactor and the experimental incorporation of tungsten as a competitive antagonist of molybdenum yields enzymatically inactive XOR in various animal systems. Feeding rats on a tungsten-supplemented molybdenum-free diet results in synthesis of inactive XOR and reduces liver XOR enzymatic activity to less than $10 \%$ of initial values. However, although XOR enzymatic activity is presumably also reduced in their mammary glands, neither the delivery of normal litters nor the growth of pups is affected in tungsten-treated mothers. Liver XOR activity is undetectable in those pups while nursed by tungsten-treated mothers, but rises dramatically after weaning, since the administration of molybdenum rapidly reconstitutes the enzymatic activity of $\mathrm{XOR}$. These studies suggest that the pups receive tungsten and inactive de-molybdo XOR through milk, yet it had no impact on the maternal mammary glands (Cohen et al. 1974; Johnson et al. 1974). Feeding tungsten to lactating goats and cows also shows a strong decrease of milk XOR enzymatic activity in both cases without any influence on milk yield (Owen and Proudfoot 1968). Interestingly, milk contains by nature a mixture of active and inactive (de-molybdo) XOR (McGartoll et al. 1970; Ventom et al. 1988). While the enzymatic activity of milk XOR changes over time, the level of XOR protein remains relatively constant (Brown et al. 1994, 1995). Oral administration of sodium molybdate to cows and goats increases only the molybdenum content in milk, but does not alter the activity of milk XOR and also does not cause changes in milk fat content or milk yield (Kiermeir and Capellari 1958; Hart et al. 1967). Furthermore, in vitro experiments have shown that application of the XOR enzymatic inhibitor allopurinol does not affect terminal differentiation of mammary cells (Hayden et al. 1991). All the above results are consistent with a nonenzymatic role for XOR protein in milk fat droplet secretion.

TEM analysis of isolated MFGM reveals the existence of an intervening coat material between the inner face of the MFGM bilayer and the outer face of the fat droplet monolayer. The coat material is a protein layer composed of plasma membrane proteins associated with selected cytosolic proteins, as well as proteins from the surface of the cytoplasmic lipid droplets. XOR and bu- 
tyrophilin (BTN) have been identified as the major proteins forming this coat material (Franke et al. 1981). BTN, a member of the Ig superfamily, is a type I membrane glycoprotein unique to the mammary gland, and the most abundant protein of bovine and guinea pig MFGM. Interestingly, coimmunoprecipitation studies with the cytoplasmatic domain of BTN suggest specific binding to XOR, and correlate with previous findings that XOR is tightly associated with the cytoplasmic surface of the apical epithelial membrane (Ishii et al. 1995; Keenan and Patton 1995). BTN can also be covalently bound to XOR by bifunctional cross-linking agents (Valivullah and Keenan 1989). The aggregation of a BTN/ XOR complex may subsequently trigger the binding of additional molecules to form the protein core. The major fat droplet surface protein, likely to be involved in protein core formation during envelopment, is the adipocyte differentiation-related protein (ADRP). ADRP is frequently associated with the surface of cytoplasmic lipid droplets, and together with XOR and BTN is a major component of the protein core (Heid et al. 1996). Immunohistochemical analysis of early lactating mammary tissue, as well as of milk from wild-type and $X O R+/-$ mice, revealed no differences in the expression of ADRP and MUC-1, a MFGM protein of the mammary epithelium (data not shown). It has been reported that BTN and XOR are expressed in constant molar proportions in bovine MFGM and these proportions vary with breed and stage of lactation. Particularly, XOR as a homodimer may simultaneously bind two BTN molecules and therefore be responsible for the observed accumulation of BTN molecules on budding membrane areas (Mather et al. 2001). A likely explanation for the up-regulation of XOR during lactation is the high cellular demand for this structural molecule, since it is continuously lost from the cell with each budding fat droplet. The TEM analyses in Figures 5 and 6 show partially enveloped fat droplets in $X O R+/-$ mammary glands. An attractive hypothesis is that only the membrane with enough localized XOR protein can successfully envelop a milk fat droplet. Other areas with less or no XOR may be either missing the apical membrane or are enveloped by cytoplasmic crescents of various lengths.

Our current model for the role of XOR in milk fat droplet enveloping is as follows: after parturition, the MFGM converts a significant amount of XOR from the $\mathrm{XD}$ to the $\mathrm{XO}$ form. This conformational change may allow XO to then interact with the cytoplasmic portion of BTN from the apical plasma membrane, leading to an accumulation of BTN at future membrane budding areas. BTN and XO may interact directly or indirectly with surface proteins from the CLDs, presumably ADRP. Additional cytosolic proteins, proteins from the surface of CLDs, and proteins from the apical membrane may interact with $\mathrm{BTN}, \mathrm{XO}$, and ADRP to form an entire protein core between the apical membrane and the surface of the CLDs. The formation of the protein core presumably triggers the binding of the apical membrane to the CLD, resulting in tight enveloping and subsequent budding of the milk fat droplets from the mammary epithe- lial cells (Heid et al. 1996, 1998; Mather and Keenan 1998; McManaman et al. 1999). Since XOR molecules are constantly lost from the lactating mammary epithelium and are therefore in high demand, the reduction in the amount of XOR protein in $X O R+/-$ mice leads to numerous defects in milk fat droplet enveloping, the destruction of the mammary epithelium, and premature involution of the mammary gland.

In the context of evolution, we suggest that the housekeeping enzyme XOR became one of the key (structural) proteins that allow fat droplets to be secreted and thereby creating a new cell function in a new cell type of the class mammalia. $X O R$ is not the only housekeeping gene that performs an additional role in evolution. Studies on vertebrate and invertebrate lens proteins show that several metabolic housekeeping genes have been recruited as taxon-specific structural lens proteins (crystallins), the major proteins in refractive eye lenses. This phenomenon, the use of a gene and its encoded protein for more than one function, has been termed "gene sharing" (Wistow and Piatigorsky 1987; Piatigorsky and Wistow 1989). While some of the crystallin proteins retain full enzymatic activity, others have reduced or unknown enzymatic activity (Zigler and Rao 1991). Just as for XOR in milk fat droplet secretion, the enzymatic activity of crystallin proteins may not be required for the additional structural role in the lens. Gene sharing of $X O R$ in the lactating mammary gland, an evolutionarily young organ, provides a striking example of a gene acquiring multiple functions during its evolution. How the additional role of XOR in milk fat droplet secretion and its presence in milk may have impinged on the evolutionary development of the mammary gland will be addressed in a separate communication (C. Vorbach and M.R. Capecchi, in prep.).

As mentioned above, humans with mutations in $X O R$ suffer from xanthinuria; however, lactation problems have not been reported in these patients. This is particularly striking, since already a heterozygous mutation of $X O R$ in mouse causes the destruction of the lactating mammary epithelium, mortally affecting the ability to nurse. A potential explanation for this difference between mice and humans is that mice have a milk fat content of $20 \%-30 \%$, whereas human milk contains only about $4 \%$ fat. This suggests that a mutation in the $X O R$ gene and a defect in milk fat droplet secretion may have a much stronger impact on the lactating murine mammary gland than on human lactation. Furthermore, the nature of the mutation (point mutations, deletions) should differentially affect the functionality of XOR in the mammary gland. Still, about $5 \%$ of women experience primary lactation insufficiency (Neifert 2001), and $X O R$ is a potential candidate gene for contributing to this deficiency.

In summary, we have shown that mice heterozygous for a loss-of-function mutation in $X O R$ are unable to maintain lactation. The disruption of lactation is caused by a $X O R$-dependent defect in the enveloping of milk fat droplets with the apical mammary epithelial membrane, thereby markedly interfering with secretion of those 
droplets into the milk, causing tissue necrosis and induction of premature involution of the mammary gland.

\section{Materials and methods}

Cloning of a targeting vector for xanthine oxidoreductase

$X O R$ was cloned from a 129 SvJ Lambda Fix II genomic library (Stratagene). Based on the published $X O R$ cDNA sequence (Terao et al. 1992), synthetic oligonucleotide probes homologous to regions of exons 3 and 5, were used in the library screen ensuring that the recovered clones contained the most proximal redox active center of XOR. The oligonucleotide probe for exon 3 had the sequence: $5^{\prime}$-TGTGCGGGACCAAGCTTGGCTGTG GAGAAGGTGGCT-3'. The oligonucleotide probe for exon 5 had the sequence $5^{\prime}$-CATTCTCGATCTCCTCGACAGTAGG CTCAGGCTTGTTTCGGAG-3'. An 8.8-kb EcoRI fragment, surrounding exon 3 , was isolated from the genomic library and used as the homologous region in the targeting vector. A replacement vector was generated by inserting a GFP/loxP/tACECre/neo ${ }^{r} / \operatorname{lox} P$ cassette at a unique HindIII site in exon 3 (Bunting et al. 1999). The linearized targeting vector was electroporated into R1 ES cells (Nagy et al. 1993) and ES cells enriched for the targeting event were selected with the drugs G418 and FIAU. These ES cells were screened for accurate gene targeting via Southern blot analysis. Correctly targeted ES clones were injected into C57BL/6J-derived blastocysts and then transferred to uteri of pseudopregnant mice. Chimeric males estimated to contain $>80 \%$ ES cell contribution were mated with BL6 females to obtain germline transmission at the mutant $X O R$ allele (A.J. Scriven and M.R. Capecchi, in prep.).

\section{Body weight analysis and dissection of pups}

Each of six litters (three from wild-type and three from $X O R+/-$ mothers) was reduced to the same size of six pups and the body weight increase was documented for each pup from lactation day 1 to 13 . The average body weight of the wild-type and $X O R+/-$ litter $(\mathrm{n}=18)$ was calculated as means \pm S.D. for each lactation day. Pups were euthanized with $\mathrm{CO}_{2}$, dissected, and analyzed macro- and microscopically.

\section{Histology}

Mammary glands \#4 were removed from wild-type and XOR+/mice, immediately cut into four pieces, and fixed in $4 \%$ Paraformaldehyde/PBS overnight. The fixed glands were washed for $3 \times 10 \mathrm{~min}$ in PBS and paraffin embedded (Paraplast X-tra, CMS) with the help of a Modular Vacuum Processor (Instrumentation Laboratory) and a Tissue Embedding Center (Reichert-Jung) according to standard methods. Six-micrometer tissue sections were mounted on pretreated glass slides (Superfrost Plus Micro Slides, VWR), mounted with D.P.X. (Aldrich) and observed using a Leitz Ortholux II with a 3CCD digital color camera (DAGE-MTI).

\section{Whole-mount analysis}

Mammary glands \#3 were removed from wild-type and XOR+/mice at different lactation days and immediately spread onto glass slides. After drying the glands to the slides for about $1 \mathrm{~min}$, the glands were fixed in Carnoy's fixative ( 3 vol 100\% EtOH, 1 vol glacial acetic acid) overnight. The glands were washed in $70 \% \mathrm{EtOH}$ for $20 \mathrm{~min}$, rinsed in water, and stained with carmine alum stain $(2.5 \mathrm{~g}$ alum potassium sulfate, $1 \mathrm{~g}$ indigo car- mine, $500 \mathrm{~mL}$ water) overnight, washed in water, dehydrated, and mounted.

\section{Semithin sections and electron microscopy}

Mammary glands \#4 were removed from wild-type and XOR+/mice, cut in very small pieces, and fixed overnight (phosphate buffer at $\mathrm{pH} 7.4$ containing $2 \%$ glutaraldehyde and $1 \%$ paraformaldehyde). The tissue was postfixed in $2 \%$ osmium tetroxide buffered with phosphate buffer at $\mathrm{pH} 7.4$ for $2-4 \mathrm{~h}$, dehydrated and embedded with the EMbed 812 Kit (Electron Microscopy Sciences). Blocks were randomly sectioned (1 $\mu \mathrm{m}$-thick and stained with $1 \%$ toluidine blue $/ 1 \%$ sodium borate in water for light microscopy analysis (Leitz Ortholux II with a 3CCD digital color camera, DAGE-MTI). For electron microscopy, random areas of mammary glands were thin sectioned with the aid of a diamond knife mounted on an ultramicrotome (LKB Nova Leica). The thin sections $(60-80 \mathrm{~nm})$ were counterstained with uranyl acetate and lead citrate before the ultrastructural samples were observed, using a transmission electron microscope (Hitachi H-7100, University of Utah, Research Microscopy Facility).

\section{Enzymatic activity}

Mammary glands \#4 from wild-type and $\mathrm{XOR+/-} \mathrm{mice} \mathrm{were}$ collected and shock frozen with liquid nitrogen. Enzymatic analysis was performed according to (Beckman et al. 1989) with minor modifications. The tissue was homogenized in $2 \mathrm{~mL}$ of 50 $\mathrm{mM}$ potassium phosphate at $\mathrm{pH} 7.4 / 0.1 \mathrm{mM}$ EDTA and protease inhibitor (Complete, Roche) followed by sonication. The cell lysates were centrifuged at $18,000 \mathrm{~g}$ for $30 \mathrm{~min}$ at $4^{\circ} \mathrm{C}$. Of the supernatant, $100 \mu \mathrm{L}$ was diluted to $2 \mathrm{~mL}$ with $50 \mathrm{mM}$ potassium phosphate/0.1 mM EDTA. Fluorescence was monitored at 390 $\mathrm{nm}$ with the excitation wavelength set at $345 \mathrm{~nm}$. After achieving a stable baseline, $20 \mu \mathrm{L}$ of $1 \mathrm{mM}$ pterin and $20 \mu \mathrm{L}$ of $1 \mathrm{mM}$ methylene blue were added as an electron acceptor to assay total XOR activity for $2 \mathrm{~min}$. To inhibit and to confirm the specificity of the reaction, $20 \mu \mathrm{L}(2 \mathrm{mM})$ allopurinol was added and the XOR activity reached a plateau. $20 \mu \mathrm{L}(1 \mu \mathrm{M})$ isoxanthopterin was added as an internal standard after its exact concentration was determined spectrally $\left(\mathrm{E}_{336}=13.0 \mathrm{mM}^{-1} / \mathrm{cm}^{-1}\right)$. XOR activity was expressed as micromolar of isoxanthopterin formed/minutes per milligram protein. The total protein concentrations in the above-described supernatants were determined by dye-binding assay (Bio-Rad Laboratories) according to manufacturer's instructions.

\section{Milk analysis}

Pups were removed for $2-5 \mathrm{~h}$ before milking the mothers. Mice were anesthetized with avertin $(450 \mu \mathrm{L} / 25 \mathrm{~g}$ body weight $)$ and injected intraperitoneally with Oxytoxin (0.3 IU; Sigma) in 200 $\mu \mathrm{L}$ PBS. After a 5-10-min incubation period milk was withdrawn with a Pasteur pipette attached to tubing and a mouth piece. For creamatocrit analysis, an estimation of total milk lipid content, 10 wild-type and $10 \mathrm{XOR}+/$ - mice were milked on lactation day 2 . The milk was spun in a haematocrit centrifuge and the fat content was estimated using Spiracrit, a micro-hematocrit capillary tube reader (Lancer; Lucas et al. 1978). For milk protein analysis, three wild-type and three $X O R+/-$ mice were milked on 5 consecutive days and $0.5 \mu \mathrm{L}$ milk was analyzed with SDS-PAGE using a $15 \%$ resolving and a 5\% stacking gel. 


\section{Acknowledgments}

We thank Marjorie Allen, Carol Lenz, Gail Peterson, Jim Hayes, Sheila Barnett, and Julie Tomlin for ES culture work and blastocyst injection, the vivarium staff for help with animal care, Nancy Chandler for help with electron microscopy, Tom Huecksteadt for help with the enzymatic assay, Gurmail Gill for help with the creamatocrit analysis, Thomas Keenan for the ADRP antibody, Sandra Gendler for the MUC-1 antibody, and members of the Capecchi lab for critical reading of the manuscript.

The publication costs of this article were defrayed in part by payment of page charges. This article must therefore be hereby marked "advertisement" in accordance with 18 USC section 1734 solely to indicate this fact.

\section{References}

Abadeh, S., Killacky, J., Benboubetra, M., and Harrison, R. 1992. Purification and partial characterization of xanthine oxidase from human milk. Biochim. Biophys. Acta 1117: 25-32.

Amaya, Y., Yamazaki, K., Sato, M., Noda, K., and Nishino, T. 1990. Proteolytic conversion of xanthine dehydrogenase from the NAD-dependent type to the $\mathrm{O}^{2}$-dependent type. Amino acid sequence of rat liver xanthine dehydrogenase and identification of the cleavage sites of the enzyme protein during irreversible conversion by trypsin. J. Biol. Chem. 265: 14170-14175.

Beckman, J.S., Parks, D.A., Pearson, J.D., Marshall, P.A., and Freeman, B.A. 1989. A sensitive fluorometric assay for measuring xanthine dehydrogenase and oxidase in tissues. Free Radic. Biol. Med. 6: 607-615.

Bray, R.C., Barber, M.J., Dalton, H., Lowe, D.J., and Coughlan, M.P. 1975. Iron-sulphur systems in some isolated multicomponent oxidative enzymes. Biochem. Soc. Trans. 3: 479482.

Brown, A.M., Benboubetra, M., Ellison, M., Reckless, J.D., and Harrison, R. 1994. Molecular activity of human milk xanthine oxidase varies with time after parturition. Biochem. Soc. Trans. 22: 444S.

Brown, A.M., Benboubetra, M., Ellison, M., Powell, D., Reckless, J.D., and Harrison, R. 1995. Molecular activation-deactivation of xanthine oxidase in human milk. Biochim. Biophys. Acta 1245: 248-254.

Bunting, M., Bernstein, K.E., Greer, J.M., Capecchi, M.R., and Thomas, K.R. 1999. Targeting genes for self-excision in the germ line. Genes \& Dev. 13: 1524-1528.

Capecchi, M.R. 1989. Altering the genome by homologous recombination. Science 244: 1288-1292.

Carpani, G., Racchi, M., Ghezzi, P., Terao, M., and Garattini, E. 1990. Purification and characterization of mouse liver xanthine oxidase. Arch. Biochem. Biophys. 279: 237-241.

Cazzaniga, G., Terao, M., Lo Schiavo, P., Galbiati, F., Segalla, F., Seldin, M.F., and Garattini, E. 1994. Chromosomal mapping, isolation, and characterization of the mouse xanthine dehydrogenase gene. Genomics 23: 390-402.

Chung, H.Y., Song, S.H., Kim, H.J., Ikeno, Y., and Yu, B.P. 1999. Modulation of renal xanthine oxidoreductase in aging: Gene expression and reactive oxygen species generation. J. Nutr. Health Aging 3: 19-23.

Cohen, H.J., Johnson, J.L., and Rajagopalan, K.V. 1974. Molecular basis of the biological function of molybdenum. Devel opmental patterns of sulfite oxidase and xanthine oxidase in the rat. Arch. Biochem. Biophys. 164: 440-446.

Dent, C.E. and Philport, G.R. 1954. Xanthinuria, an inborn error (or deviation) of metabolism. Lancet 266: 182-185.
Engerson, T.D., McKelvey, T.G., Rhyne, D.B., Boggio, E.B., Snyder, S.J., and Jones, H.P. 1987. Conversion of xanthine dehydrogenase to oxidase in ischemic rat tissues. J. Clin. Invest. 79: 1564-1570.

Enroth, C., Eger, B.T., Okamoto, K., Nishino, T., and Pai, E.F. 2000. Crystal structures of bovine milk xanthine dehydrogenase and xanthine oxidase: Structure-based mechanism of conversion. Proc. Natl. Acad. Sci. 97: 10723-10728.

Franke, W.W., Heid, H.W., Grund, C., Winter, S., Freudenstein, C., Schmid, E., Jarasch, E.D., and Keenan, T.W. 1981. Antibodies to the major insoluble milk fat globule membraneassociated protein: Specific location in apical regions of lactating epithelial cells. J. Cell Biol. 89: 485-494.

Freudenstein, C., Keenan, T.W., Eigel, W.N., Sasaki, M., Stadler, J., and Franke, W.W. 1979. Preparation and characterization of the inner coat material associated with fat globule membranes from bovine and human milk. Exp. Cell Res. 118: 277-294.

Fridovich, I. 1970. Quantitative aspects of the production of superoxide anion radical by milk xanthine oxidase. J. Biol. Chem. 245: 4053-4057.

Ghosal, D., Shappell, N.W., and Keenan, T.W. 1994. Endoplasmic reticulum lumenal proteins of rat mammary gland. Potential involvement in lipid droplet assembly during lactation. Biochim. Biophys. Acta 1200: 175-181.

Granger, D.N., Hollwarth, M.E., and Parks, D.A. 1986. Ischemia-reperfusion injury: Role of oxygen-derived free radicals. Acta Physiol. Scand. Suppl. 548: 47-63.

Hart, L.I., Owen, E.C., and Proudfoot, R. 1967. The influence of dietary molybdenum on the xanthine oxidase activity of the milk of ruminants. Br. J. Nutr. 21: 617-630.

Hayden, T.J., Brennan, D., Quirke, K., and Murphy, P. 1991. Xanthine oxidase/dehydrogenase in mammary gland of mouse: Relationship to mammogenesis and lactogenesis in vivo and in vitro. J. Dairy Res. 58: 401-409.

Heid, H.W., Winter, S., Bruder, G., Keenan, T.W., and Jarasch, E.D. 1983. Butyrophilin, an apical plasma membrane-associated glycoprotein characteristic of lactating mammary glands of diverse species. Biochim. Biophys. Acta 728: 228238.

Heid, H.W., Schnolzer, M., and Keenan, T.W. 1996. Adipocyte differentiation-related protein is secreted into milk as a constituent of milk lipid globule membrane. Biochem. I. 320: 1025-1030.

Heid, H.W., Moll, R., Schwetlick, I., Rackwitz, H.R., and Keenan, T.W. 1998. Adipophilin is a specific marker of lipid accumulation in diverse cell types and diseases. Cell Tissue Res. 294: 309-321.

Hille, R. and Nishino, T. 1995. Flavoprotein structure and mechanism. 4. Xanthine oxidase and xanthine dehydrogenase. FASEB J. 9: 995-1003.

Hunt, J. and Massey, V. 1992. Purification and properties of milk xanthine dehydrogenase. J. Biol. Chem. 267: 2147921485.

Huston, G.E. and Patton, S. 1990. Factors related to the formation of cytoplasmic crescents on milk fat globules. J. Dairy Sci. 73: 2061-2066.

Ishii, T., Aoki, N., Noda, A., Adachi, T., Nakamura, R., and Matsuda, T. 1995. Carboxy-terminal cytoplasmic domain of mouse butyrophilin specifically associates with a $150-\mathrm{kD}$ protein of mammary epithelial cells and milk fat globule membrane. Biochim. Biophys. Acta 1245: 285-292.

Jarasch, E.D., Bruder, G., Keenan, T.W., and Franke, W.W. 1977. Redox constituents in milk fat globule membranes and rough endoplasmic reticulum from lactating mammary gland. J. Cell Biol. 73: 223-241. 
Jarasch, E.D., Grund, C., Bruder, G., Heid, H.W., Keenan, T.W., and Franke, W.W. 1981. Localization of xanthine oxidase in mammary-gland epithelium and capillary endothelium. Cell 25: $67-82$.

Johnson, J.L., Waud, W.R., Cohen, H.J., and Rajagopalan, K.V. 1974. Molecular basis of the biological function of molybdenum. Molybdenum-free xanthine oxidase from livers of tungsten-treated rats. J. Biol. Chem. 249: 5056-5061.

Keenan, T.W. 2001. Milk lipid globules and their surrounding membrane: A brief history and perspectives for future research. J. Mammary Gland Biol. Neoplasia 6: 365-371.

Keenan, T.W. and Patton, S. 1995. The structure of milk: Implications for sampling and storage. The milk lipid globule membrane. In Handbook of milk composition (ed. R.G. Jensen), pp. 5-50. Academic Press, Inc., New York.

Kiermeir and Capellari. 1958. Biochem Z. 330: 160.

Kurosaki, M., Li Calzi, M., Scanziani, E., Garattini, E., and Terao, M. 1995. Tissue- and cell-specific expression of mouse xanthine oxidoreductase gene in vivo: Regulation by bacterial lipopolysaccharide. Biochem J. 306: 225-234.

Kurosaki, M., Zanotta, S., Li Calzi, M., Garattini, E., and Terao, M. 1996. Expression of xanthine oxidoreductase in mouse mammary epithelium during pregnancy and lactation: Regulation of gene expression by glucocorticoids and prolactin. Biochem J. 319: 801-810.

Linder, N., Rapola, J., and Raivio, K.O. 1999. Cellular expression of xanthine oxidoreductase protein in normal human tissues. Lab Invest. 79: 967-974.

Long, C.A. and Patton, S. 1978. Formation of intracellular fat droplets: Interrelation of newly synthesized phosphatidylcholine and triglyceride in milk. J. Dairy Sci. 61: 1392-1399.

Lucas, A., Gibbs, J.A., Lyster, R.L., and Baum, J.D. 1978. Creamatocrit: Simple clinical technique for estimating fat concentration and energy value of human milk. Br. Med. J. 1: 1018-1020.

Mangino, M.E. and Brunner, J.R. 1977. Compositional homology of membrane-protein systems and membrane-associated proteins: Comparison with milk fat globule membrane and 'membrane'-derived xanthine oxidase. I. Dairy Sci. 60: 1208-1216.

Massey, V., Brumby, P.E., and Komai, H. 1969. Studies on milk xanthine oxidase. Some spectral and kinetic properties. $I$. Biol. Chem. 244: 1682-1691.

Mather, I.H. 2000. A review and proposed nomenclature for major proteins of the milk-fat globule membrane. J. Dairy Sci. 83: 203-247.

Mather, I.H. and Keenan, T.W. 1998. Origin and secretion of milk lipids. J. Mammary Gland Biol. Neoplasia 3: 259-273.

Mather, I.H., Sullivan, C.H., and Madara, P.J. 1982. Detection of xanthine oxidase and immunologically related proteins in fractions from bovine mammary tissue and milk after electrophoresis in polyacrylamide gels containing sodium dodecyl sulphate. Biochem J. 202: 317-323.

Mather, I.H., Jack, L.J., Madara, P.J., and Johnson, V.G. 2001. The distribution of MUC1, an apical membrane glycoprotein, in mammary epithelial cells at the resolution of the electron microscope: Implications for the mechanism of milk secretion. Cell Tissue Res. 304: 91-101.

McCord, J.M. 1985. Oxygen-derived free radicals in postischemic tissue injury. N. Engl. J. Med. 312: 159-163.

McGartoll, M.A., Pick, F.M., Swann, J.C., and Bray, R.C. 1970. Properties of xanthine oxidase preparations dependent on the proportions of active and inactivated enzyme. Biochim. Biophys. Acta 212: 523-526.

McManaman, J.L., Neville, M.C., and Wright, R.M. 1999. Mouse mammary gland xanthine oxidoreductase: Purifica- tion, characterization, and regulation. Arch. Biochem. Biophys. 371: 308-316.

McManaman, J.L., Hanson, L., Neville, M.C., and Wright, R.M. 2000. Lactogenic hormones regulate xanthine oxidoreductase and $\beta$-casein levels in mammary epithelial cells by distinct mechanisms. Arch. Biochem. Biophys. 373: 318-327.

Nagy, A., Rossant, J., Nagy, R., Abramow-Newerly, W., and Roder, J.C. 1993. Derivation of completely cell culture-derived mice from early-passage embryonic stem cells. Proc. Natl. Acad. Sci. 90: 8424-8428.

Neifert, M.R. 2001. Prevention of breastfeeding tragedies. Pediatr. Clin. North Am. 48: 273-297.

Owen, E.C. and Proudfoot, R. 1968. The effect of tungstate ingestion on xanthine oxidase in milk liver. Br. I. Nutr. 22: 331-340.

Parks, D.A. and Granger, D.N. 1983. Ischemia-induced vascular changes: Role of xanthine oxidase and hydroxyl radicals. Am. J. Physiol. 245: G285-G289.

Piatigorsky, J. and Wistow, G.J. 1989. Enzyme/crystallins: Gene sharing as an evolutionary strategy. Cell 57: 197-199.

Rajagopalan, K.V. and Handler, P. 1967. Purification and properties of chicken liver xanthine dehydrogenase. I. Biol. Chem. 242: 4097-4107.

Schardinger, F. 1902. Ueber das Verhalten der Kuhmilch gegen Methylblau und seine Verwendung zur Unterscheidung von ungekochter und gekochter Milch. Z. Untersuch. Nahrungs. Genussmittel 5: 1113-1121.

Terao, M., Cazzaniga, G., Ghezzi, P., Bianchi, M., Falciani, F., Perani, P., and Garattini, E. 1992. Molecular cloning of a cDNA coding for mouse liver xanthine dehydrogenase. Regulation of its transcript by interferons in vivo. Biochem. J. 283: 863-870.

Valivullah, H.M. and Keenan, T.W. 1989. Butyrophilin of milk lipid globule membrane contains $\mathrm{N}$-linked carbohydrates and cross-links with xanthine oxidase. Int. I. Biochem. 21: 103-107.

Ventom, A.M., Deistung, J., and Bray, R.C. 1988. The isolation of demolybdo xanthine oxidase from bovine milk. Biochem. J. 255: 949-956.

Waud, W.R. and Rajagopalan, K.V. 1976. The mechanism of conversion of rat liver xanthine dehydrogenase from an NAD+-dependent form (type D) to an O2-dependent form (type O). Arch. Biochem. Biophys. 172: 365-379.

Williamson, D.H. 1990. The lactating mammary gland of the rat and the starved-refed transition: A model system for the study of the temporal regulation of substrate utilization. Biochem. Soc. Trans. 18: 853-856.

Wistow, G. and Piatigorsky, J. 1987. Recruitment of enzymes as lens structural proteins. Science 236: 1554-1556.

Zaczek, M. and Keenan, T.W. 1990. Morphological evidence for an endoplasmic reticulum origin of milk lipid globules obtained using lipid-selective staining procedure. Protoplasma 159: 179-182.

Zigler Jr., J.S. and Rao, P.V. 1991. Enzyme/crystallins and extremely high pyridine nucleotide levels in the eye lens. FASEB I. 5: 223-225. 


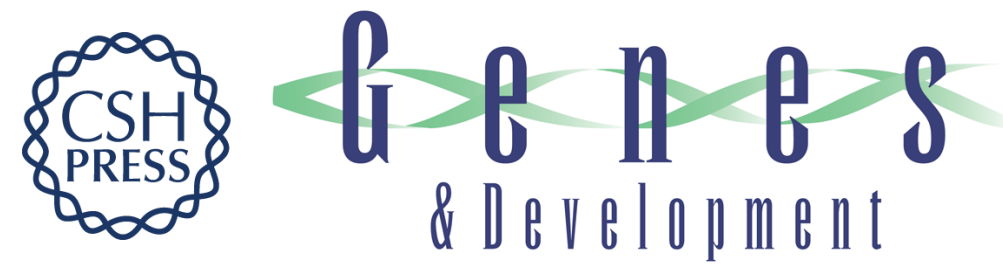

\section{The housekeeping gene xanthine oxidoreductase is necessary for milk fat droplet enveloping and secretion: gene sharing in the lactating mammary gland}

Claudia Vorbach, Alistair Scriven and Mario R. Capecchi

Genes Dev. 2002, 16:

Access the most recent version at doi:10.1101/gad.1032702

$\begin{array}{ll}\text { References } & \begin{array}{l}\text { This article cites } 56 \text { articles, } 17 \text { of which can be accessed free at: } \\ \text { http://genesdev.cshlp.org/content/16/24/3223.full.html\#ref-list-1 }\end{array}\end{array}$

License

Email Alerting Receive free email alerts when new articles cite this article - sign up in the box at the top Service right corner of the article or click here.

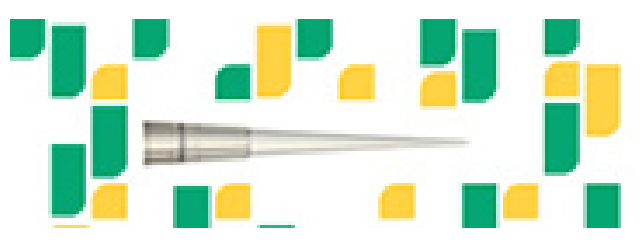

Focused on your science. 